UDC $340.12+1: 316.3$

DOI: https://doi.org/10.21564/2075-7190.40.155761

Kovalenko Inna Igorivna, Candidate of Philosophy, Associate Professor, Associate Professor of Philosophy Department, Yaroslav Mudryi National Law

University, Kharkiv, Ukraine

e-mail: kinna087@gmail.com

ORCID ID: 0000-0001-9320-1773

Kalnytskyi Eduard Anatolievich, Candidate of Philosophy, Associate Professor, Associate Professor of Philosophy Department, Yaroslav Mudryi National Law

University, Kharkiv, Ukraine

e-mail: kalnitsky@ukr.net

ORCID ID: 0000-0002-1777-9992

\title{
CONCEPTUAL DIMENSIONS OF LEGAL LIFE: GNOSIOLOGICAL ASPECT
}

The article shows the phenomenological understanding of law as the horizon of the world of life. It is substantiated that the semantic characteristics of the world of life define the context of an integrative interpretation, whose purpose is to understand the meanings of law contained in the structures of consciousness. Specifically defined content of the concept of legal life in its semantic dimensions. In conclusion, that in the epistemological aspect legal life can be defined as a form of potential content of law, which is realized in the activity of the subject of law, actual forms of legal consciousness, and is primary in relation to theoretical assertion about the law.

Keywords: social cognition, phenomenology of law, integrative legal thinking.

Actuality of investigated issue. Social phenomenology is today one of the important areas of scientific research. It acts as a theoretical and methodological concept that considers society as a constituent world of meanings, mutually agreed rules and variations of human activity forms. The reception of methodology and categorical apparatus of phenomenology, the extension of the principles of nonclassical rationality to the theory of law are the basis for the development of integrative legal thinking as a perspective version of modern legal thinking.

Analysis of scientific publications. In modern philosophy of law there is a considerable number of works devoted to theoretical problems of the study of the phenomenon of law. At the same time, scholars emphasize that in the field of philosophical, legal, and legal research there is a noticeable methodological shortage due to the uncertainty of the scientific status of the philosophy of law [10-12], the

(c) Kovalenko I. I., Kalnytskyi E. A., 2019 
crisis of classical legal thinking types (both positivism and jusnatalism) [13; 14], the substitution of legal phenomena by their dogmatic presumptions $[15 ; 16]$, the excessive pluralization of legal thinking [17], the lack of consistency between the constant terminology and the movement of social life [18]. By the heuristic potential of phenomenology in the study of law also apply lawyers [19; 20]. However, the problem of finding the epistemological foundations of legal life as a semantic legal entity is still practically not worked out.

Paper aim formulation. The study of the concept of legal life implies the use of certain methodological tools, in particular, the principle of the integrity of ontology and gnoseology. It is to be considered that understanding of the principle essentials differs from the interpretations, generally accepted in the classical methodology of social cognition. This distinctive feature is related to the phenomenological reduction, determining the dependence of legal life forms and phenomena on meaning-making function of the consciousness. Therefore, this principle expresses the unity of the intentional experience aspects: the formation of the consciousness thingness and its understanding. The gnoseological perspective points at the meaning of an object itself, while the ontological perspective focuses on finding its figural meaning. Their integrity is ensured by proactive synthesizing activity of the consciousness.

According to the abovementioned the aim of the paper is to present heuristic possibilities of the legal life concept to study law in the gnoseological aspect.

Results and Discussion. The gnoseological perspective is essential in the phenomenology of law. In fact, legal life is constituted primarily as the area of conscious human activity, which gradually gains a certain actual form. In this aspect it is described using conceptual dimensions, which may be defined as evident understanding of law. They determine potential opportunities of constituting law, enable to transfer to the perception of legal life as given and the description of it as the conceptual boundary of the life space.

While studying legal life problems more thoroughly from the gnoseological perspective it is also necessary to consider the specifics of the phenomenological perception of the world from the perception, typical of the classical legal science. They differ in the focus on ordering conceptual relations between the possibilities and reality of law. In particular, scientific perception of the world is based on the retrospective logic. According to it law is understood as the result of the historical events and phenomena, as a sequence of selected implemented and unimplemented possibilities of today's reality of law. In other words, the area of scientific research involves only those phenomena that do not contradict its methodology and are based on the evidence from the variety of legal phenomena. Consequently, the thus reduced law is formed as a theoretical-logical substruction, which "embraces what is conceptually incognizable from experience in its own existence" [1, p. 176]. 
Eventually, using a series of interim idealizations, law is compared to its own specific pre-scientific existence.

Criticizing retrospective nature of scientific reasons, $\mathrm{H}$. Bergson identified the specifics of this logic as follows: "It definitely projects the past as the opportunities of virtualities, today"s realities, and thus, what currently consists of parts, has always been viewed by it that way ... It is not willing to believe that if these elements did not appear as real, they would not have existed before as opportunities, since the possibility of a thing is always... a mirage of the existing reality, which is thrown away to the endless past. Our logic ousts into the past, deemed as possible, the reality appearing at present, because it does not recognize that something appears, forms, and that the time is efficient" [2, p. 133].

An alternative to the scientific truths reversal motion logic is phenomenological logic, under which law is the horizon of the life world. It is the thing given that moves into the future while being recognized. Despite its continuous evolution, law still seeks to learn its final truth and mission. Phenomenological perception provides for immersing into the given pre-predicative life world, and then moving towards the horizon of law. Thus, at each stage of the phenomenological research concepts are specified and legal phenomena gain their aims, the research expands the field of the issues considered and its prospects, shifts them into the future.

E. Husserl defined phenomenological research features saying that any cognition of laws might be only the cognition of the prospects of existing and potential phenomena of experience, the cognition of certain, perceived as laws forecasts, which would get clear outlines along with gaining experience... and would be inductively confirmed [1, p. 76]. The legal life concept involves its own expression of the motion to potential law horizon, involves, since it includes the description of its form and content by moving from and $t o$.

It is to be noted that this ascend is regulated by a number of phenomenological procedures. First of all, law as the horizon of lie world must be open by the continuous improvement of phenomenological reduction, which is designed to exclude all the provisions that are not limited to what is actually given in the consciousness. At the next stage of the research the factual nature of life processes was found. It makes phenomenology return to its initial descriptive objective. Therewith, description provides the researcher with an opportunity to freely manipulate the worldview imagery and freely handle it [3, p. 78]. At this stage there emerges a possibility, staying on the basis of the life world, to study legal life as the horizon of its newly-created concepts and conceptualization.

The need to single out legal life conceptual dimensions implies specifying the content of E. Husserl theory of life world. The demarcation line between phenomenology and classical science creates a new worldview as the entirety that is not segmented into themes, which serves the precondition for understanding the 
aim of human activities and constituting new social concepts. The athematic entirety as the essential feature of the life world is made of several conceptual segments, whose deployment corresponds to the gradual sequence of using phenomenological logic.

Projectivity, the orientation of the phenomenological logic on the future is a reason why contemporary philosophers attend a lot to the life world problems. For example, N. V. Motroshylova states that the term Lebenswelt has already shifted from the dedicated philosophical, phenomenological field to a wide space of public life - for example, into politics and mass media practices [4, p. 102]. The scholar also comprehensively analyzed the life world theory. As a result of the analysis she presented an interesting approach to pointing out conceptual segments of life world. Their composition is determined by the following conceptual features: life world is the only existing world, life world as forgotten sensuous scientific foundation, life world always presupposed and given; life world is the realm of primary evidence, life world is the actual world of life.

Suppose that these life world conceptual features are compatible with the content of the legal life concept. However, it is necessary to take into account that this correlation must not be similar to causative or general-specific relations. Legal life concept shows law as one of the regions of life world. In its turn, life world establishes the ground and horizon of law. Therewith, conceptual features of the life world are designed to set the context of the legal life integrative interpretation, aiming at the establishment of the interrelations between the given and the concepts, emerging in the inner structure of consciousness.

Thus, if legal life is considered in the context of the conceptual segment running that life world is the only existing world, it is presented there as the original generalization, direct experience of studying law, which lacks scientific abstractions and usual views. However, this lack is temporary since scientific idealizations coexist and are interwoven with legal practices. The specifics of this conceptual segment of legal life are in the fact that here law appears not only as a certain structure of legal consciousness, but also as a life-practice modulus and the active aspect of all communications: from standard routine contacts in domestic world to legal interrelations in the state. At the same time legal life is actual, because it is factual by nature, i.e. self-evident and value-based attractiveness of the communications.

The idea of justice may serve an example of legal life expression as the existing legal world. The content of the idea sometimes seems so evident that it is generally accepted to appeal to this idea in any circumstances of professional and nonprofessional intrusion in the area of legal relations. However, even initial analysis of interpretations of the idea of justice (justice as a virtue, justice as equal opportunities, justice as the expression of human reason, justice as the rule of law 
etc.) demonstrate that the idea has its internal (conceptual) and external (objective) dimensions. From the standpoint of the former dimension justice is incorporated into the conceptual structure of law and is related to such its basic ideas as order, peace, equality and freedom. From the latter standpoint justice is presented as equal-sized totality of conditions, specific means of their implementation in legal consciousness and legal practices. Further, though in the internal dimension the idea of law is self-evident, universal and self-sufficient, externally it exists only as an opportunity, determined by specific content of actions, relations, interests and motives. In this case it cannot be considered as their autonomous and direct regulator. The above found controversy between different dimensions is to clarify that in fact justice as an idea, mindset and evaluation is the legal given, which is expressed in certain, known conditions of communication within a specific sociocultural context.

The second conceptual segment of the life world stating that the life world is the forgotten sensuous scientific foundation specifies the settings of the previous segment and draws attention to the opportunity to understand legal life as the world of pre-scientific experience. This enables to imagine legal life before the establishment of states, property, sanctioned punishment etc. In other words, it is possible to imagine legal life beyond the conventions of scientific explanation of the world, and also question the reliability of scientific statements. The grounds for this skepticism are apparent: legal science has not managed to explain the internal logic of its development, the need of certain concepts, provisions and theories.

Unlike the law as the subject of objective science, in this context legal life is presented as the process of accumulating, constituting and symbolizing socially meaningful concepts for people to be oriented on in their everyday activities. Since the world is limited not by borders, but by activated internal content [5, p. 165], it is possible to suggest that the growth of understanding the world is congruent with the increasing meaning of the legal regulations and scientific theories.

This suggestion is also confirmed by the explanation of the third conceptual segment that the life world is also presupposed and given. The wording of the segment, being interpreted in the context of the classical rationality, must bring properties of fatalism and determinism into the legal life concept. However, for E. Husserl the given nature of the life world is related to its transcendental genesis, which ensures its perpetual and known significance as being. Life world appears given by itself without any provisional predication, and this property applies to law as a fragment of life world as well. The inherent value of law is determined by its ability to form the ideas of the normal life. Modern German phenomenologist B. Waldenfels explains the nature of this ability by the processes of habitualization. He emphasizes that the rules in force are not the tables of the covenant and the superstitions that are well visible. They are shown to every person as something to 
rely on, as a habit. The idea of normal life dates back to the past, preceding our own experience (primary habitus), and later it enables to modify or expand the existing rules consciously (secondary habitus) [6, p. 88]. Levels and forms of legal consciousness, exercised in the perception of regulations, are not merely given in legal life, but they play the leading role there. V. A. Bachinin notes that speaking about the legal consciousness, according to the logic of phenomenological analysis, inside the external-empirical shell there is the transcendental Ego, which promotes the creation of structures and nature, transformed into moral and legal rules and values at the upper level of consciousness... Phenomenology shifts the dominant of the normativity from the external transcendence of the world to the internal transcendental one [7, p. 938]. Therefore, a person turns out to be not a puppet to be manipulated in any way, but a subject that considers the law both as the form of everyday life regulation, and as the way of confirming their social significance.

The significance of the law in everyday life is also found and confirmed by the content of the fourth life world conceptual segment saying that the life world is the realm of primary evidence. Under which conditions does law become as evident as the objects perceived here and now? Perhaps, when a person realizes his or her involvement in legal processes, that is his or her intentions and expectations coincide with the established norms and rules of public relations. The conditions of the involvement in legal processes must be habitual for the person. Non-exclusivity and the normal nature of legal involvement do not appear by themselves. They are formed from outside, considering person's interests, by formally established and non-established lie world institutions. In this context it is meaningless to maintain long scientific and publicist disputes on the priority means of forming legal culture. For instance, it is totally insignificant to learn what the condition of the person's abilities to coexist, exercise and act was, according to the rights and responsibilities. This may be the natural moral feeling of own dignity, religion-based beliefs in the common compassion, legal education or legal professional advice.

The habitual and accessible nature of the things given in law is the precondition for singling out standards, inter alia, in the form of rules, behavior patterns, stable reactions to repeated situations out of them. A. Schütz stated that in the face-to-face situation these standards are vital. Intersubjectivity of legal interactions immanently contains norms as the condition of renewing ourselves. Acquiring norms, their transition from the external obligation to the internal imperative depends on the degree of their evidence for the subject. Defining the evidence as the correlation between the interest and knowledge distribution, A. Schütz pointed out four areas of perceived importance: 1) the world directly surrounding a person is the area of primary importance; 2) the areas of insignificant importance, which stand for readymade tools to achieve goals - it is enough to know opportunities, chances and the level of risk, which may hamper satisfying person's main interest; 3 ) the areas of 
relative unimportance, currently unrelated to the existing interest; 4) the area of total unimportance, which will never enter the field of person's interests, and no change there may ever influence the resolution of person's problems [cited by: 8 , p. 161].

To our mind, the application of the evidence and importance scale to legal life studies, provided by A. Schütz, is highly promising. Firstly, it may become a sample integrative survey, which goes beyond the subject matter of sociology, psychology, management theory and so on. Secondly, it allows us to comprehensively solve such topical issues of the contemporary western European and domestic legal culture as legal nihilism, dysnomia and deviation.

The research into the burning problems of law provides for addressing the fifth conceptual segment that the life world is the actual world of life. Literally, E. Husserl's setting to orient philosophy on the world of actual experience, where people live and act, preceded the emergence of the life world theory. While in the classical modal logic the concept of the actual acquires the content only in relation to the concepts of potential and possible, Husserl's philosophical theory states that the actual, or present (Jetzt) is the evidence of authenticity and person's presence in the world. The topicality as the authenticity is revealed as the antithesis of assumptions of the objective science on eternity and universality of existence.

It is to be mentioned that the intention to find something already given in law has always been inherent in any classical understanding of law. It has been a birthmark of objectivism and is determined by its aim: to find the laws in the conditions of person's existence, which would be similar to the eternal laws of nature. The existential reasons of this human consciousness aberration were clearly described by V. V. Bibikhin who remarked that we feel that there are such things as fate... that orders us to do something and prohibits other things. It is hard to identify this feeling, and we search for the support of our existence in established rules and norms. Nobody would ever will to have these norms and rules imposed on us by the same people as we are. The source of law must be deeper and more reliable than human thoughts and regulations... it is also inappropriate to dwell on the recent laws as they were formulated by ourselves. Law-makers believe that they express popular will [9, p. 15].

The research into the life world of law in phenomenology also seems to provide for the historical clarity. However, this clarity immanently contains all the aspects of human activities. N. V. Motroshylova rightly remarks that Husserl's criticism of naturalism and objectivism of the classical science brings him back to the philosophy of history by K. Marx. It is common knowledge that he insisted that the existence in philosophy should not be taken as the object or observation, but as the human sensuous activities and practices [4, p. 136]. In other words, the existing law is the condition and the result of the human creative activities. The tautology of actual 
via activity is justified here. Indeed, the active presence and involvement in law or legal life implies that the subject is actively involved in the law, he or she acquires it practically, acting or refraining from actions in compliance with the norms of law, and spiritually, imagining law as the value and making theories about it.

The focus should also be on the fact that the criticism of the classical understanding of law does not mean denying the value of law science itself. It has its bases in the life world, similarly to other human activities. Paraphrasing the reasoning on the historical mission of sciences by E. Husserl, it is possible to affirm that whether the law sciences are clear or unclear, significant or insignificant, they, similarly to all good and bad instrumental forms of mankind, are incorporated into the world as real experience [1, p. 346]. The phenomenology of law and law science create the common subject field of law. However, they reflect its different horizons, since they approach its acquisition in different but content-and-genetically related ways. In the first case, it is practical and mental acquisition, whereas in the other theoretical.

Legal life also preserves the attribute of topicality because it returns to the subject his or her rights, will, needs, interests, right to reason etc. These subject's expressions were pushed to the background in the universal abstraction of the law subject. As a result, the subject of law has transformed into a form of world perception from the live, deep-rooted in history human communities and their institutions. The interconnection between the topicality and subjectivity of legal life is based on the transformation of legal concepts into the aim and action plan, that is into what is normally called acquisition. In E. Husserls' terminology acquisition in the meaning of the condition of life world was named as selfconsciousness, oriented on clarifying the totality of willing and active life in relation to what Ego actually wishes, what it seeks in life. The result of this work on selfawareness is the formation of understanding of the harmonized style of further life in general [1, p. 361].

Thus, the interpretation of the legal life phenomenon in the context of the life world theory enables to reorient classical understanding of law onto the grounds, from which it actually originates, and which are the foundation of its significance. This interpretation of the legal life concept provides an opportunity to specify its content due to the following conceptual dimensions: 1) legal life is the existing world of law; 2) legal life is the lost foundation of legal sciences; 3) legal life precedes the scientific and theoretical acquisition of law; 4) legal lie is the area of evident statements on law; 5) legal life is the existing law.

Summarizing the abovementioned features and descriptions of the conceptual segments of the legal life concept, it is possible to state that the conceptual dimensions are intentional implications (in E. Husserl's terminology). They set the modes of law constitution, potential directions of its phenomenological cognition. 
Phenomenological methodology and life world theory return law science to its origins and enable to find the law as the continuously moving horizon of acquiring the existing world. Thus, gnoseologically, legal life is considered as a form conceptual content of law, which precedes theoretical statements on it. Legal life is made of primary given understanding of law, expressed in comprehensible and evident ideas rule of law limits.

\section{ЛITЕРАТУРА}

1. Гуссерль Э. Кризис европейских наук и трансцендентальная феноменология. Введение в феноменологическую философию. Санкт-Петербург : Владимир Даль, 2004. $400 \mathrm{c}$.

2. Бергсон А. Введение к сборнику «Мысль и движущееся». Часть первая. Возрастание истины. Возвратное движение истины. Bопросы философии, 2007. № 8. C. $125-134$.

3. Блюменберг Х. Жизненный мир и технизация с точки зрения феноменологии. Вопросы философии. 1993. № 10. С. 64-93.

4. Мотрошилова Н. В. Понятие и концепция жизненного мира в поздней концепции Эдмунда Гуссерля. Вопросы философии. 2007. № 7. С. 102-112.

5. Луман Н. Общество как социальная система; пер. с нем. Москва : Логос, 2004. $232 \mathrm{c}$.

6. Вальденфельс Б. Происхождение норм жизненного мира. Мотив чужого / пер. с нем. Минск : Пропилеи, 1999. 175 с.

7. Бачинин В. А. Энциклопедия философии и социологии права. Санкт-Петербург : Изд-во Р. Асланова «Юрид. центр Пресс», 2006. 1091 с.

8. Шульц В. Л. Методология социального познания А. Щюца. Вопросы философии. 2008. № 1. С. 152-162.

9. Бибихин В. В. Введение в философию права. Москва : ИФ РАН, 2005. 343 с.

10. Керимов Д. А. Методология права (предмет, функции, проблемы философии права) : монография. Москва : Аванта+, 2001. 560 с.

11. Козюбра М. І. Місце філософії права в системі суспільствознавства (до питання про дисциплінарний статус філософії права). Проблеми філософії права. 2003. T. 1. C. 27-32.

12. Костицький М. В. Філософські та наукознавчі проблеми юриспруденції (як науково-практичного комплексу) та окремих галузей юридичної науки. Філософські та методологічні проблеми права. 2013. № 1-2. С. 3-10.

13. Костицький М. В. Нормативізм як методологія юриспруденції. Філософські та методологічні проблеми права. 2016. № 1. С. 19-30.

14. Стовба О. В. Право і час : монографія. Харків : Тім Пабліш Груп, 2016. 368 с.

15. Рабинович П. М. Філософія права: деякі «вічнозелені» наукознавчі сюжети. Право України. 2011. № 8. С. 13-20.

16. Дробышевский С. А., Орлова С. В. О так называемых «мертвых» юридических нормах в политически организованном сообществе. Актуальные проблемы фи- 
лософии права и юридической науки в связи с коммуникативной теорией права : монография / под. ред. М. В. Антонова, И. Л. Честнова. Санкт-Петербург : ООО Издательский Дом «Алеф-пресс», 2014. Т. II. С. 342-347.

17. Толстик В. Борьба за содержание права - важнейшее научное направление. Право України. 2010. № 4. С. 29-35.

18. Антонов М. В. О принципах научности и развитии правовой теории. Стандарты научности и homo juridicus в свете философии права : материалы пятых и шестых философ.-правовых чтений памяти акад. В. С. Нерсесянца. Москва : Норма, 2011. C. $143-153$.

19. Несинова С. В. Інтегральна правова концепція в дослідженні правових інститутів. Право і суспільство. 2014. № 6-1, ч. 2. С. 33-39.

20. Веприцький Р. С. Феноменологія злочинності як галузь кримінології. Форум права. 2013. №3. С. 84-87.

\section{REFERENCES}

1. Gusserl' E. (2004). Krizis evropejskih nauk i transcendental'naya fenomenologiya. Vedenie v fenomenologicheskuyu filosofiyu. Sankt-Peterburg: Vladimir Dal' [in Russian].

2. Bergson A. (2007). Vvedenie k sborniku «Mysl' i dvizhushcheesya». CHast' pervaya. Vozrastanie istiny. Vozvratnoe dvizhenie istiny. Voprosy filosofii-Problems of philosophy, 2007, 8, 125-134 [in Russian].

3. Blyumenberg H. (1993). ZHiznennyj mir i tekhnizaciya s tochki zreniya fenomenologii. Voprosy filosofii - Problems of philosophy, 1993,10, 64-93 [in Russian].

4. Motroshilova N. V. (2007). Ponyatie i koncepciya zhiznennogo mira v pozdnej koncepcii EHdmunda Gusserlya. Voprosy filosofii-Problems of philosophy, 2007, 7, 102-112 [in Russian].

5. Luman N. (2004). Obshchestvo kak social'naya sistema. Moskva: Izdatel'stvo «Logos» [in Russian].

6. Val'denfel's B. (1999). Proiskhozhdenie norm zhiznennogo mira. Motiv chuzhogo. Minsk: Propilei [in Russian].

7. Bachinin V. A. (2006). EHnciklopediya filosofii i sociologii prava. Sankt-Peterburg: Izd-vo R. Aslanova «YUrid. centr Press» [in Russian].

8. SHul'c V. L. Metodologiya social'nogo poznaniya A. SHCHyuca. Voprosy filosofiiProblems of philosophy, 2008, 1, 152-162 [in Russian].

9. Bibihin V. V. (2005). Vvedenie v filosofiyu prava. Moskva: IF RAN [in Russian].

10. Kerimov D. A. Metodologiya prava (predmet, funkcii, problemy filosofii prava). Moskva: Avanta [in Russian].

11. Koziubra M. I. (2003). Mistse filosofii prava v systemi suspilstvoznavstva (do pytannia pro dystsyplinarnyi status filosofii prava). Problemy filosofii prava-Problems of philosophy of law, 1, 27-32 [in Ukrainian].

12. Kostytskyi M. V. (2013). Filosofski ta naukoznavchi problemy yurysprudentsii (iak naukovo-praktychnoho kompleksu) ta okremykh haluzei yurydychnoi nauky. Filosofski 
ta metodolohichni problemy prava - Philosophical and methodological problems of law, 1-2, 3-10 [in Ukrainian].

13. Kostytskyi M. V. (2016). Normatyvizm yak metodolohiia yurysprudentsii. Filosofski ta metodolohichni problemy prava - Philosophical and methodological problems of law, 1, 19-30 [in Ukrainian].

14. Stovba O. V. (2016). Pravo i chas. Kharkiv: Tim Pablish Hrup [in Ukrainian].

15. Rabynovych P. M. Filosofiia prava: deiaki «vichnozeleni» naukoznavtsi siuzhety. Pravo Ukrainy - Low of Ukraine, 8, 13-20 [in Ukrainian].

16. Drobyshevskij S. A., Orlova S. V. (2014). O tak nazyvaemyh «mertvyh» yuridicheskih normah v politicheski organizovannom soobshchestve. Aktual'nye problemy filosofii prava i yuridicheskoj nauki v svyazi s kommunikativnoj teoriej prava. Sankt-Peterburg: OOO Izdatel'skij Dom «Alef-press», Vol. II [in Russian].

17. Tolstik V. (2010). Bor'ba za soderzhanie prava - vazhnejshee nauchnoe napravlenie. Pravo Ukrainy - Low of Ukraine, 4, 29-35 [in Ukrainian].

18. Antonov M. V. (2011). O principah nauchnosti i razvitii pravovoj teorii. Standarty nauchnosti $i$ homo juridicus $v$ svete filosofii prava : materialy pyatyh $i$ shestyh filosof.-pravovyh chtenij pamyati akad. V.S. Nersesyanca. Moskva: Norma [in Russian].

19. Nesinova S. V. (2014). Integral'na pravova koncepciya v doslidzhenni pravovih institutiv. Pravo i suspil'stvo - Law and society, 6-1. ch. 2, 33-39 [in Ukrainian].

20. Vepric'kij R. S. (2013). Fenomenologiya zlochinnosti yak galuz' kriminologiï. Forum prava-Law forum, 3, 84-87 [in Ukrainian].

Коваленко Інна Ігорівна, доцент, доцент кафедри філософії Національного юридичного університету імені Ярослава Мудрого, м. Харків, Україна

Кальницький Едуард Анатолійович, доцент, доцент кафедри філософії Національного юридичного університету імені Ярослава Мудрого, м. Харків, Україна

\section{СМИСЛОВІ ВИМІРИ ПРАВОВОГО ЖИТТЯ: ГНОСЕОЛОГІЧНИЙ АСПЕКТ}

Актуальність досліджуваної проблеми. Соціальна феноменологія виступає сьогодні як теоретико-методологічна конщепиія, щео розглядає суспільство як конституйований світ смислів, взаємоузгоджених правил та варіацій форм людської діяльності. Рецепиія методології та категоріального апарату феноменології, поширення принципів некласичної раціональності на теорію права є засадою для розвитку інтегративного праворозуміння як перспективної версії сучасного праворозуміння. 
Аналіз наукових публікацій. Хоча в науковій літературі визнана продуктивність феноменологічного дослідження права, у наявних дослідженнях поки що відсутня цілісна концепція розуміння правового життя.

Метою статті $\epsilon$ показ евристичних можливостей концепту «правове життя» для дослідження права у гносеологічному аспекті.

Статтю присвячено гносеологічному аспекту правового життя у рамках феноменології. Автори виходять з того, щзо правове життя конституюється передусім як простір осмисленої діяльності людей, яка згодом набуває тієї чи іншої форми фактичності. У такому аспекті діяльність людей описується з допомогою смислових вимірів, які можна визначити як очевидні уявлення про право. Вони визначають потениійні можливості конституювання права, дозволяють перейти до сприйняття правового життя у безпосередній даності та опису його як смислової межі життевого світу.

Показана відмінність феноменологічного пізнання світу від пізнання, властивого класичній науці про право. Визначені особливості феноменологічної логіки. Конизепт «правове життя» представлений як вираження процесу сходження до можливих горизонтів права.

Обгрунтована сумісність смислових характеристик жсттєвого світу зі змістом кониеепту «правове життя». Так, по-перше, у контексті смислового блока «життєвий світ - єдино дійсний світ» смисл права визначатиметься як життєвий практичний модус діяльності й контекст усіх комунікацій - від тих, щуо регулюються за рахунок повсякденних контактів, до правових взаємодій, щзо регулюються державою. Другий смисловий блок життєвого світу «життєвий світ як забутий чуттєвий фундамент науки» дає можливість осмислити правове жсття як світ донаукового досвіду, у якому правове життя являє собою процес накопичення, інституціоналізацї та символізації сочіально значущчих смислів, щзо ними керуються люди в їхній повсякденній діяльності. Третій блок - «правове життя завжди передує науково-практичному розвитку права» дозволяє вважати, щзо внутрішня иінність права обумовлена здатністю суб 'єкта формувати уявлення про «нормальне життя». Четвертий блок «правове життя - иче простір очевидних висловлювань»: смисл права полягає в усвідомленні та артикуляиії суб 'єкта, його присутності в юридичних процесах, а також у виділенні стандартів, норм, моделей поведінки, стійких реакцій на повторювальні ситуаціі. П'ятий блок «правове життя - цее дійсне право» передбачає, щуо суб 'єкт входить у право, опановує його, діє або не діє відповідно до закону, бере участь у створенні законів, розуміє право як иінність та форму суспільної свідомості.

Зроблений висновок, щ⿻ смислові виміри - цуе інтенціональні імплікації (термінологія Е. Гуссерля). Вони задають модуси конституювання права, можливі напрями його феноменологічного пізнання. Феноменологічна методологія та вчення про життєвий світ повертають науку про право до своїх засад та дозволяють виявити право як такий, щзо постійно відсовується, «горизонт» актуального освоєння світу. У гносеологічному аспекті правове життя розглядається як форма смислової змістовності права, яка передує теоретичним твердженням про нього. Правове жит- 
тя утворене вихідними даностями правосвідомості, які виражаються у вигляді доступних та очевидних уявлень про межі правового порядку.

Ключові слова: сочіальне пізнання, феноменологія права, інтегративне праворозуміння.

Коваленко Инна Игоревна, кандидат философских наук, доцент, доцент кафедры философии Национального юридического университета имени Ярослава Мудрого, г. Харьков; Украина

Кальницкий Эдуард Анатолиевич, кандидат философских наук, доцент, доцент кафедры философии Национального юридического университета имени Ярослава Мудрого, г. Харьков, Украина

\section{СМЫСЛОВЫЕ ИЗМЕРЕНИЯ ПРАВОВОЙ ЖИЗНИ: ГНОСЕОЛОГИЧЕСКИЙ АСПЕКТ}

В статье показано феноменологическое понимание права как горизонта жизненного мира. Обосновано, что смысловые характеристики жизненного мира задают контекст интегративной интерпретации права, изелью которой является понимание смыслов права, содержашихся в структурах сознания. Конкретизировано содержание кониепта правовой жизни в его смысловых измерениях. Сделан вывод, что в гносеологическом аспекте правовая жизнь может быть определена как форма потенциальной смысловой содержательности права, реализующаяся в деятельности субъекта права, актуальных формах правосознания и являющяаяся первичной по отношению к теоретическим утверждениям о праве.

Ключевые слова: сочиальное познание, феноменология права, интегративное правопонимание.

\section{soxes}

